\title{
Vertical Living Vs Sustainable Communities: Open Space Design within High Density Urban Neighbourhoods in Hong Kong
}

\author{
SBA Coorey \\ Department of Architecture, University of Moratuwa \\ sbacoorey@gmail.com
}

\begin{abstract}
Open space is an important urban design element with high social, environmental and economic value, and is an important determinant for building sustainable communities. In Hong Kong the open spaces allocated within vertical neighbourhoods act as extended semi-public living spaces from the otherwise tight private living spaces. This paper focuses on such open spaces which are designed and allocated for communal activity. In the case of hyper dense cities such as Hong Kong the attributes of urban compactness and mixed use, have implications on the quality of open space, impacting the residents' satisfaction and use of such spaces. Such implications hamper the quality of open space and thereby its influence on building sustainable communities. Literature identifies some negative factors such as the lack of open space provisions, crowding, lack of privacy, lack of greenery and poor environmental quality and positive factors such as reduced travel time, better social contact and safety in open spaces. This paper tests the impact such factors have on the overall satisfaction and use of open space in vertical neighbourhoods. Questionnaire surveys are conducted in selected high density neighbourhoods in Hong Kong in order to collect data on open space evaluations by the residents. Statistical analysis is done to identify the significant variables influencing optimal user satisfaction and its implications on building sustainable communities in vertical neighbourhoods.
\end{abstract}

Key Words: Open Space, Compact Neighbourhoods, Vertical Living, Sustainable Communities

\section{Introduction}

Urban open space is critical for social, environmental and economic sustainability and better quality of life. The three key benefits of local open spaces that are discussed by Chiesura (2003) are environmental and ecological benefits, social and psychological benefits and economic benefits. Such benefits contribute to city space and the quality of life and are key indicators for sustainability. Chris and Blake (2000) and Clawson and Knetch (1969) discuss the social and environmental benefits of open space such as open space facilitates recreation, gathering places for social interaction and civic function, link neighbourhoods and buffer incompatible uses. It also acts as a habitat for flora and fauna, support life and afford scenic views, control floods, purify run off and recharge ground water.
A high density compact urban form is associated with negative characteristics such as perceived lack of open space provisions, crowding, lack of privacy, lack of greenery, poor environmental quality and some positive characteristics such as reduced travel time, better social contact and higher levels of safety as compared to low density sprawling urban forms (Jacobs 1961; Burgess, Harrison et al. 1988; Coupland 1997; Robertson and Jones 1997; Helling 1998; Rowley 1998; Burton 2000; Jenks 2000; Masnavi 2000; Zaman, Lau et al. 2000; Burton 2002 ; Department 2003; Coorey and Lau 2005).

Urban open spaces play an important role in vertical high dense urban environments. They help to facilitate social interactions and sustain communities, provided that such spaces are habitable outdoor urban spaces that act as an 
extended living space. In the case of high dense vertical living achieving such habitable urban open spaces is a challenge.

The building density, due to demands for built up areas, high levels of mix land uses has implications on the habitability of its open space in terms of its social and physical quality but it can be argued that implications of such an urban environment can also be positive. High densities may provide safer urban spaces, better contact with community and hence interaction. Yet it can also foster lack of privacy, overcrowding, lack of greenery and soft landscape, climatic discomfort, noise, pollution etc. Such factors will have implications on the overall satisfaction, use and the habitability of open space in high rise neighbourhoods.

The habitability of open spaces in high density contexts, need to be addressed, if vertical neighbourhooods are to foster sustainable communities. This paper identifies critical factors having implications on the habitability of open spaces considering 6 high rise vertical neighbourhoods with population density ranging from 1000persons/ha to 3000 persons/ha.

Results will generate the factors that are considered as critical for the habitability of open spaces in high rise vertical neighbourhoods. In that light urban planners and designers can focus on such factors in creating more habitable open spaces for the future in high dense vertical living environments.

\section{Review of Hong Kong Fabric}

Hong Kong is situated at the Southeastern tip of China, ideally positioned at the centre of rapidly developing East Asia. HKSAR is a relatively small and high density city in which available land for building is scarce. The total population of Hong Kong is 7, 136,300 (Census and Statistics Department, 2012). Total land area of Hong Kong is 1, 108 square kilometers and only $21.8 \%$ is built up due to topographic constraints where $78.2 \%$ of land is hilly and not readily available for development. This results in high population density in the built up areas. The built-up land is mainly concentrated in the triangular tip of Kowloon and the coastal strip of northern Hong Kong Island (Figure 1).
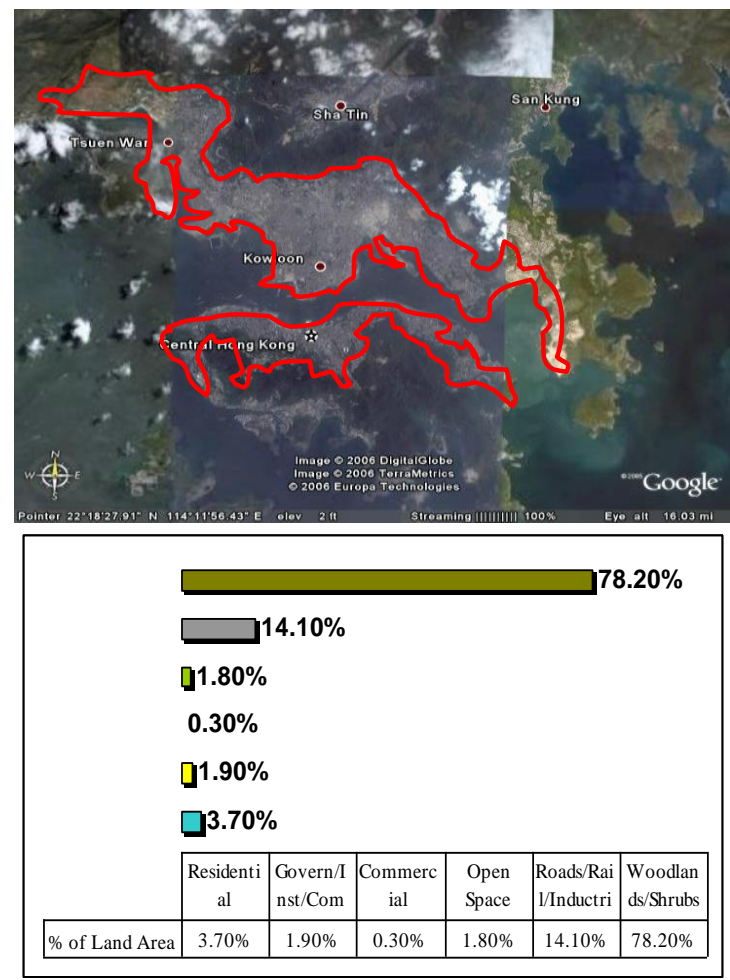

Figure 1: Distribution of Built Area and Land Uses in Hong Kong.

A population growth rate of approximately 1 million is observed in every 10 years in the last decade and the population forecast for 2030 is 9 million (Fung 2001). Although the total population density of Hong Kong is 6,440 persons/sq.km, density distribution in Hong Kong Island and Kowloon urban areas show high densities with certain districts in Kowloon ranking among the most densely populated places in the world with over 55,000 persons $/ \mathrm{sq} . \mathrm{km}$. The density in public housing reaches at least 2500 , residents/ha which is twice the density of the most crowded residential areas in mainland China (Xue, Kevin et al. 2001). Such pressures impact the private living space per person, and also public open space provisions having adverse effects on the living standards and quality of life. Provisions for open space in urban Hong Kong is 1.5 sq.m per person which is low in comparison to other Asian cities such as Guangzhou (3 sq.m/person), Shenzhen (2 sq.m./person), Taipei (2sq.m/person), Singapore (4 sq.m./person) and Tokyo (6 sq.m./person). 
High rise intensified mixed land use developments are built around the mass transit nodes in and around city centers. The plot ratio of such developments is up to 10 for residential uses and 15 for commercial uses leading to high rise towers up to 80 storeys' (Lau, Ghiridharan et al. 2003). These developments are horizontally integrated by mass transit rail, subways below ground; buses, taxis, light rail transit and tramways on ground and walkways above ground. Vertically integration takes place via ramps, stairways, elevators and escalators. A single cluster is defined as a primary Multiple Intensive Land Use (MILU) node with primary land uses such as residential, office, hotel and secondary land uses such commercial, Government Institutional and Community and recreation (Lau, Ghiridharan et al. 2003). A combination of activities take place below ground, on ground, on podium and above podium levels as seen in Figure 2. Open spaces are located above ground on podiums in order to save land for other uses.

\subsection{Challenges for Open Spaces in Hong Kong}

The need for good quality habitable open spaces within the living areas of high dense environments such as Hong Kong is critical for sustaining its communities. A Hong Kong resident's private life goes beyond his home into public gathering places like shopping malls, restaurants, karaoke bars, parks, open spaces known as borrowed spaces (Hughes 1968). The most popular form of leisure among the Hong Kong population is passive recreation in planted areas and sitting out areas within neighbourhoods (local open spaces) (Davies 1998). Economic group of households earning less than HK\$5,000/US\$ 640 per month spend more than $36 \mathrm{~h} /$ week on leisure more than any other income group (Davies 1998). As in the Hong Kong's demographic trend show aged population above 65 years increased from $10.7 \%$ in 1999 to $11.9 \%$ in 2004. Being commonly observed as high users of passive recreation such trends add more pressure on the need for passive open space.
Also open space being predominantly located on podiums is with artificial ground with minimum green turf, trees and soft landscaping. The physical dimension of open space is also limited or bound by the podium area. The hard landscaping, the high rise towers that create stagnant hot air by blocking the wind circulation aggravate the micro climatic conditions of these open spaces. But one could argue that such open spaces are buffered from the noise and polluted air of highways and traffic, yet some open spaces located on ground levels adjacent to highways and vehicular traffic are being exposed to constant noise and air pollution.

Most public housing developments have single primary land use which is residential and supported by shopping mall, markets, schools, health centres, recreational facilities and open spaces. Private housing developments mostly have more than one primary land uses such as office, hotels and residential, with accompanying secondary land uses such as shopping malls, supermarkets, cinemas, recreation centres, open spaces, primary and secondary schools, kindergartens, banks and other community and institutional facilities. Such integration of mix uses creates open spaces that are used by a variety of user groups and active at all times. Residents as well as visitors to the developments use such spaces arising in conflicts between users and deprivation of privacy. Some developments have open spaces that are exclusive to the residents to address this issue. In additions the numbers of users are many due to the mix of uses and the location of transport nodes in close proximity or within the development. Hence there are large crowds of users creating crowded open spaces throughout the day and till late nights. But such spaces have surveillance at all times due to the high use, and are often not isolated and are safe for its users, which is a positive aspect.

The pros and cons of these spaces are many, but how the users perceive and react to such aspects will influence the habitability of such spaces and its contribution to sustaining vertical living and communities. 


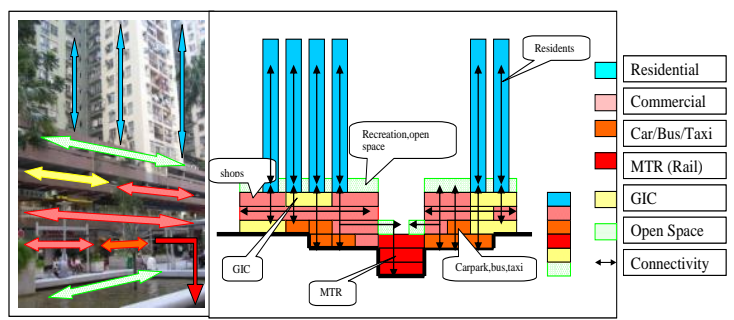

Figure 2: Conceptual Diagram of a MILU Cluster development in Hong Kong

Source: Edited by Lau, Ghiridharan et al. 2003

\section{Criteria for Habitable Open Space}

Factors affecting quality and satisfaction of open space are classified as accessibility, congestion/crowding levels, comfort, variety of activity, facilities, quality, safety, attractiveness, maintenance and user characteristics (Erkip, 1997) . According to Pasaogullari (2004) the physical and psychological access to public spaces is a basic consideration for all open space planning. Whyte (2000) identifies accessibility; people engaged in activity, comfortable space with good image, sociable space where people meet each other and increased social interaction is provided are four qualities to make successful public space. Accessibility to public space is argued as one of the most effective factors for increased use and interaction in a public space. As discussed by Erkip (1997) access to a public space depends on either travel time or proximity or both. Heng and Chan (2000) identifies the four physical designable criteria for public spaces; 1. Physical dimensions, 2. Microclimate, 3. Amenities, 4. Activities. Aesthetic considerations or physical attractiveness and maintenance are also among the most important factors for successful public space. Study done by Joardar (1993) includes background data of respondents such as income, family structure, total family income per month, family size and age as variables determining the perceptions and use of parks.

\section{Research Issue and Objectives}

Literature review defined the criteria for habitability of open space. Also the importance of open spaces in any living environment is already established. Therefore paper make the assumption that open space is critical for sustaining communities, but in the case of a high dense scenario the attention needed for open space quality is further established in this study.

Although literature defines qualities of open spaces that is important for habitability, such studies discuss other low dense, mid rise neighbourhoods and open spaces and their quality. Therefore this paper aims to identify which of such criteria are especially critical and important in the case of a high dense vertical living environment. Hence this study will establish the criteria relevant to achieving habitable open spaces in a vertical living environment. The issues raised under section 2.1 on "Challenges for open spaces in Hong Kong" will be tested through the user survey and analysis.

\section{Methodology}

\subsection{Case Selection}

The 6 public housing estates were selected for the study namely; Upper Wong Tai Sin, Lower Wong Tai Sin II, Fortune, Lai Kok, Choi Hung and Ping Shek estate all located within the Kowloon high density residential zone with close proximity to mass rail transit exits. 15 open spaces are selected within housing estates boundary. The open spaces are located on ground or podium and accessible to the public with no security controlled access. The estates are categorized according to its population density as; category 1: 1000-1200 per/ha, category 2: 1200-2200 per/ha and category 3: 2200-3200 per/ha (Table 1).

\subsection{Interview Survey}

600 questionnaire interviews were conducted to evaluate the open spaces. 100 random interviews were conducted; 50 on one weekday and 50 on one weekend from 10.30 a.m. to 6.30 p.m in the public areas of each case. As seen in Table 2, majority of the sample are residents, low income and economically non-active (retired, home makers or students). 
Vertical Living Vs Sustainable Communities: Open Space Design within High Density Urban Neighbourhoods in Hong Kong

\begin{tabular}{llllllll}
\hline $\begin{array}{l}\text { Cases- } \\
\text { Public Housing }\end{array}$ & Open Space & $\begin{array}{l}\text { Number } \\
\text { of Floors }\end{array}$ & $\begin{array}{l}\text { Flat sizes } \\
\text { Sq.m. }\end{array}$ & $\begin{array}{l}\text { Site } \\
\text { Area } \\
\text { Sq.m. }\end{array}$ & $\begin{array}{l}\text { Population } \\
\text { Size }\end{array}$ & $\begin{array}{l}\text { Average } \\
\text { Monthly } \\
\text { rental }\end{array}$ & $\begin{array}{l}\text { Net Population } \\
\text { Density } \\
\text { (per/ha) }\end{array}$ \\
\hline $\begin{array}{llllll}\text { Upper Wong Tai Sin } \\
\text { Lower Wong Tai Sin }\end{array}$ & OS1,OS2,OS3 & $10-41$ & $16.33-49.02$ & 44300 & 12019 & 2075 & 2713 \\
Fortune Estate & OS6,OS7 & $15-32$ & $16-50$ & 85000 & 22000 & 1650 & 2588 \\
Lai Kok Estate & OS8,OS9 & 13 & $11.45-32.24$ & 68000 & 7782 & 957 & 1144 \\
Choi Hung Estate & OS10,OS 11 & $8-20$ & $24.1-69.2$ & 109000 & 19718 & 2014 & 1809 \\
Ping Shek Estate & OS12,OS13, & $8-28$ & $30.6-38.8$ & 54000 & 13265 & 1506.5 & 2456 \\
\hline
\end{tabular}

Table 1: Case Background

\begin{tabular}{|l|l|}
\hline Description & \\
\hline User Group & $\begin{array}{l}\text { Residents }-81.3 \% \\
\text { Visitors }-18.7 \%\end{array}$ \\
\hline Gender & $\begin{array}{l}\text { Male }-42 \% \\
\text { Female }-58 \%\end{array}$ \\
\hline Age & $\begin{array}{l}\text { Less than 35 years - 25\% } \\
35-65 \text { years }-26 \% \\
\text { above 65years- 49\% }\end{array}$ \\
\hline Income & $\begin{array}{l}\text { Income below 5,000HKD(1USD }=7.8 \mathrm{HKD})-75 \% \\
\text { Above 5,000HKD }-25 \%\end{array}$ \\
\hline Education & $\begin{array}{l}\text { No education }-6.7 \% \\
\text { Primary Education }-51.5 \% \\
\text { Secondary Education }-34.8 \% \\
\text { Tertiary Education }-7 \%\end{array}$ \\
\hline Economic activity status & $\begin{array}{l}\text { Economically Active }-15 \% \\
\text { Economically Non Active - 85\% } \\
\text { (retired, home makers, students, unemployed) }\end{array}$ \\
\hline
\end{tabular}

Table 2: Demographic and socio-economic profile of sample population

\subsection{Independent and Dependent Variables and their Scales of Measurement}

Study identifies the important social and physical quality as the independent variables for studying the user satisfaction of open space in high density. Safety, crowding, interaction, privacy are social quality variables measured on a 5-point Likert scale ranging from $1=$ not at all to 5=very much. Provisions for open space, accessibility, climatic quality, maintenance/facilities and aesthetics quality are identified physical quality variables measured on 5-point Likert scale ranging from $1=$ not at all to $5=$ very much. Accessibility is measured by travel time (1=less than $5 \mathrm{mint}$, $2=5-15$ mints, $3=15-30$ mints, $4=30$ mints $-1 \mathrm{hr}$ and $5=$ more than $1 \mathrm{hr}$ ). Human factors variables type of user- if resident or visitor, age, gender, income level, education level, economic activity status, availability of time for leisure, average time spent during a visit, frequency of visits per month, leisure preference were also included as independent variables.

The dependent variable open space satisfaction was measured using a 3 item scale each rated on a 5-point Likert scale ranging from $1=$ not at all to $5=$ very much. The 3 items included; enjoy the time spent in the open space, visiting the open space is worth the time and overall satisfaction with the open space. The total minimum possible score for open space satisfaction is $3 \times 1=3$ and maximum score is $3 \times 5=15$.

Although open space quality variable were measured using a single question, the interviewers filled in the questionnaire by interviewing the respondents, using key words to describe and explain each question ensuring that respondents had a clear understanding of the questions and the rating scales of measurement. 


\subsection{Method of Analysis:}

Stepwise multiple regression analyses examined the association between open space satisfaction and social and the physical quality of open space. Human factor variables were included in the first step of the analyses. Social quality variables in step two, followed by physical quality variables in step three to determine the variables uniquely related to open space satisfaction.

\section{Findings}

As shown in Figure 3 below the analysis of mean scores achieved for each variable in each case shows that travel time to open space scores less in all cases, which is a positive factor in such high dense vertical developments. Overall mean scores for levels of crowding shows low levels although it was expected that open spaces would be crowded and uncomfortable to its users.

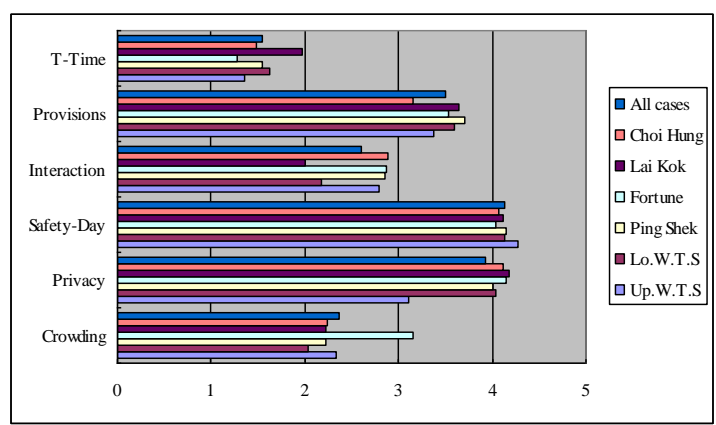

Figure 3: Mean Score Comparison of Open Space Qualities

Further step wise multiple regressions conducted to identify the significant variables influencing open space satisfaction is shown in Table 3. Step 1 includes all human factor variables where the $R$ square value of 0.267 indicates that the human factor variables account for $26.7 \%$ variation in open space satisfaction. Only age, gender, leisure preference, and duration of use per month are significant. Step 2 includes all social quality variables in addition to the significant human factors. The $\mathrm{R}$ square value of 0.354 indicates that $34.5 \%$ variance in open space satisfaction is explained by all the variables. Step 3 includes all physical quality variables in addition to the significant human factor and social quality variables. The $\mathrm{R}$ square value of 0.587 implies that all variables account for
$58.7 \%$ variance in open space satisfaction (see Table 3).

Results indicate that physical qualities of open space such as: Climatic Conditions, maintenance and facilities in open spaces and the provisions for open space is critical for user satisfaction (see Table 3). The important social qualities are: interaction, privacy and safety in open space (see Table 3).

\begin{tabular}{|llll|}
\hline \multicolumn{4}{l}{ Overall Model for critical selected variables } \\
\hline Variables & Beta & $\mathbf{t}$ & Sig \\
\hline Climate & .294 & 9.602 & .000 \\
Duration & .289 & 9.434 & .000 \\
Maintenance/ & .245 & 8.012 & .000 \\
Facilities & .137 & 4.584 & .000 \\
Interaction & .107 & 3.383 & .001 \\
Age & .104 & 3.531 & .000 \\
Provisions & .095 & 3.509 & .000 \\
Privacy & .068 & 2.408 & .016 \\
Safety & -.029 & -1.039 & .299 \\
Travel time & -.014 & -.495 & .621 \\
Crowding & $\mathbf{0 . 5 8 7}$ & & \\
\hline R Square & $\mathbf{8 3 . 8 6 9}$ & & \\
F- Statistic & $\mathbf{6 0 0}$ & & \\
Respondents & $\mathbf{6 0}$ \\
\hline
\end{tabular}

Table 3: Multiple regression model for critical variables influencing open space satisfaction

Levels of crowding do not show as a factor affecting user satisfaction. Also the negative relationship between crowding and satisfaction shows that increased crowding has a negative influence on the user satisfaction. But the mean score values for crowding as shown in Table 2 indicates that crowding has scored relatively low values in the open spaces. Although it was expected that users score high values for crowding. The reason could be the adaptive mechanism of its users to the high dense living conditions and high dense public space.

Increased safety and privacy has positive implications on user satisfaction and mean score comparison show that in all cases relatively high values of privacy and safety is achieved. The results are in line with the accepted premise that better safety is critical for open space satisfaction (Giles-Corti et al. 2005; Tinsley, Tinsley, and Croskeys 2002; 
Turel, Yigit, and Altug 2007). Results also support studies by Gedikli (2004) and Stewart (2001) that privacy is important for open space satisfaction. Results indicate that high dense vertical developments are able to achieve safety and privacy levels acceptable to its user which one could argue otherwise.

Interaction is also indicated as an important variable for user satisfaction and increased levels of interaction has a positive implication on user satisfaction in high dense vertical cases. Such results support studies by Chiesura (2003), Gedikli (2004) and Stewart (2001) although these studies were not conducted in a high dense vertical scenario. But means score comparison show that the levels of interaction achieved in the open spaces are relatively low scores all cases (Table 2). This indicates that although interaction is important for satisfaction of open spaces in high dense scenarios, such interaction levels are not achieved. Although it was expected that due to high density more frequent contact with neighbours and better interaction were possible this is actually not so.

Results show that increased provisions for open space is a significant criterion for user satisfaction, and mean score comparison show those users are relatively satisfied with the allocated open spaces. Results are in line with studies of Heng and Chan (2000) and Joardar (1993). But although compact high dense cities are argued to have less open spaces for its inhabitants and hence unattractive results show that inhabitants of all cases are satisfied with the open space provisions.

\section{Conclusions}

Open space being an important urban design element and indicator for sustaining vertical communities. Study identifies physical and social parameters important for user satisfaction and hence habitable open spaces in high dense vertical neighbourhoods in Hong Kong. Overall design considerations for open spaces in high density must prioritise physical parameters such as; climatic quality, maintenance/facilities and open space provisions and social parameters such as; interaction, privacy and safety. It was apparent that reduced travel time to open space is common to high density settings. Although high density vertical living is associated with crowding in urban spaces study shows that it is not a critical parameter for open space satisfaction in high density. Although high density is claimed to be high in social interaction, safety, crowding and low in privacy - Respondents evaluate comparatively low social interaction and crowding in open spaces and safety and privacy scores high. High density is also associated with poor environmental quality and lack of open space provisions - Respondents score comparatively high for environmental quality and provisions for open space. Reduced travel time to open spaces is also a positive factor that is special in high dense vertical neighbourhoods. The study shed light on the challenges for open spaces in Hong Kong. Design parameters must be guided by the above social and physical quality variables that are established as critical for user satisfaction in order to ensure sustainable vertical communities.

\section{Acknowledgments}

The author gratefully acknowledge the Hong Kong Housing Department, Estate Managements and occupants of Upper Wong Tai Sin, Lower Wong Tai Sin, Fortune, Lai Kok, Choi Hung and Ping Shek Estates for providing information, and permission to conduct the interview survey. 


\section{References}

Burgess, J., C. M., Harrison, et al. (1988). "People, Parks and the Urban Green: a Study of Popular meanings and Values for Open Space in the City." Urban Studies (25): 455-473.

Burton, E. (2000). "The Compact City: Just or just Compact? A Preliminary Analysis." Urban Studies 37(11): 1969-2007.

Burton, E. (2002 ). "Measuring Urban Compactness in UK Towns and Cities." Environment and Planning, Planning Design 29: 219-250.

Chan, Y. K. (1999). "Density, Crowding, and Factors Intervening in their Relationship: Evidence from a Hyper Dense Metropolis.", Social Indicators Research 48 (1): 103-124.

Chiesura, A. (2003). "The Role of Urban Parks for the Sustainable City." Landscape and Urban Planning 68: $129-138$.

Chris, N. and R. Blake (2000). "Classification and Use of Open Space in the Context of Increasing Urban Capacity." Planning Practice and Research 15 (3): 193-210.

Clawson, M. and J. L. Knetch. (1969). Economics of Outdoor Recreation. Baltimore.

Coorey, S. B. A. and S. S. Y. Lau (2005). Pilot Survey on Perceptions and Use of Open Space in Two Selected Mixed Use Residential Developments in Hong Kong. 6th International Conference on Tall Buildings. Hong Kong.

Coupland, A. (1997). Reclaiming the City:Mixed Used Development. London, E \& FN Spon.

Davies, L. (1998). Study of Leisure Habits and Recreation Preferences and Review of Chapter Four of The Hong Kong Planning Stadards and Guidlines, Final Report. P. Department. Hong Kong, Planning Department.

Department, P. (2003). Working Paper No 34 - Review of Residential Densities: Concepts and Case Study. HK2030 Study. Hong Kong, Hong Kong Planning Department: 45.

Erkip, F. (1997). "The Distribution of Urban Public Services: The Case of Parks and Recreational Services in Ankara." Cities 16(6): 353-361.

Fung, B. C. K. (2001). Planning for High Density Development in Hong Kong. Hong Kong, The Planning Department of Hong Kong.

Helling, A. (1998). "Changing Intra-metropolitan Accessibility in U.S. Evidence from Atlanta." Progress in palnning 49 (Part 2): 55-107.

Heng, C. K. and V. Chan (2000). "The Making of Successful Public Space: A Case study of Peoples Park Square." Urban Design International 5: 47-55.

Hughes, R. (1968). Hong Kong Borrowed Place - Borrowed Time. London, Andre Deutsch Ltd

Jacobs, J. (1961). The Death and Life of Great American Cities. New York, Random House.

Jenks, M. (2000). Sustainable Urban Form in Developing Countries? Compact Cities Sustainable Urban forms for Developing Countries. J. M and R. Burgess, Spon Press: 356.

Joardar, S. D. (1993). "Perceptions and Use of Residential Parks in Calucutta." Ekistics 60(362-363): 276282. 
Lau S. S Y, G., R and Ganesan, S (2003). "Policies for Implimenting Multiple Intensive land Use in Hong Kong." Journal of Housing and the Built Environment 18: 365-378.

Lau, S. S. Y., R. Ghiridharan, et al. (2003). "Policies for Implementing Multiple Intensive land Use in Hong Kong." Journal of Housing and the Built Environment 18: 365-378.

Masnavi, M. R. (2000). The Compact City in Practice: The New Millennium and the New Urban Paradigm. Achieving sustainable urban form. K. Williams, Burton, E. \& Jenks, M. London ; New York E \& FN Spon pg 64.

Pasaogullari, N. D., N. (2004). "Measuring Accessibility and Utilization of Public Spaces in Famagusta." Cities 21(3): 225-232.

Renganathan, G. (2005). Urban Design Factors Influencing Outdoor Temperature in High-rise High-density Residential Developments in the Coastal Zone of Hong Kong, The Department of Architecture. Hong Kong, The University of Hong Kong.

Robertson, M. and T. L. Jones (1997). Mixed Uses and Urban design. Reclaiming the City-Mixed Use Development. A. Coupland. London, E \& FN Spon.

Rowley, A. (1998). Planning Mixed Use Development: Issues and parctice. UK, Royal Institute of Chartered Surveyors.

Stewart, P., W \& Cole, D. N. (2001). "Number of Encounters and Experience Quality in Grand Canyon Backcountry: Consistently Negative and Weak Relationships.", Journal of Leisure Research 33(1): 106-120.

Whyte, H. W. (2000). How to turn a place around How to turn a place around: a handbook for creating successful public spaces. Project for Public Spaces. New York, Project for Public Spaces, Inc.

Xue, C. Q. L., K. Kevin, et al. (2001). "Public Space in the Old Derelict City Area - a Case Study of Mong Kok, Hong Kong.", Urban Design International 6: 15-31.

Zaman, Q. M. M., S. S. Y. Lau, et al. (2000). The compact city of Hong Kong: a sustainable model for Asia? Compact cities: sustainable Urban Forms For Developing Countries, M. Jenks and R. Burgess. London ; New York: Spon Press: 267-268. 